https://journal.uwgm.ac.id/index.php/abdimasmahakam

E-ISSN: 2549-5755

Januari 2020, Vol. 4 No. 01

Received: September 2019

Accepted: Desember 2019

Published: Januari 2020

Article DOI: http://dx.doi.org/ 10.24903/jam.v4i1.806

\title{
Pemberdayaan Kesejahteraan Keluarga sebagai Pusat Informasi Kesehatan Perempuan
}

\author{
Fitria Siswi Utami \\ Universitas 'Aisyiyah Yogyakarta \\ fitriasiswi@unisayogya.ac.id \\ Retno Mawarti \\ Universitas 'Aisyiyah Yogyakarta \\ rossa_mate@yahoo.com
}

\begin{abstract}
Abstrak
Permasalahan kesehatan reproduksi selama ini masih merupakan permasalahan yang bersentuhan erat dengan gender. Perempuan seringkali dianggap satu-satunya yang bertanggungjawab terhadap kesehatan reproduksinya. Sementara itu, kesempatan memperoleh informasi khususnya sebagai usaha preventif masih dirasa kurang oleh perempuan. Kelompok Pemberdayaan Kesejahteraan Keluarga (PKK) sebagai salah satu kelompok besar perempuan usia subur sebagai wahana yang dapat dimanfaatkan anggotanya untuk bertukar informasi. Pemanfaatan kesempatan kegiatan PKK sebagai sarana berbagi informasi dan pelaksanaan pemeriksaan deteksi kanker serviks dapat meningkatkan peran aktif masyarakat dalam upaya peningkatan derajat kesehatan perempuan. Permasalahan yang dihadapi kelompok dirumuskan bersama mitra adalah minimnya informasi untuk mereka karena sumber informasi hanya berasal dari kegiatan promosi kesehatan saat Posyandu Balita. Sementara itu, tidak semua wanita usia subur peserta PKK memiliki balita. Solusi yang diberikan adalah melatih kader dari kelompok PKK sebagai penyambung informasi kesehatan untuk perempuan.
\end{abstract}

Kata Kunci: Pemberdayaan Kesejahteraan Keluarga; PKK; informasi; perempuan.

\section{Pendahuluan}

Kanker leher rahim merupakan kanker dengan urutan kejadian kedua terbanyak setelah kanker payudara. Angka kejadian kanker leher rahim adalah 17 per 100.000 perempuan dengan $13 \%$ kasus baru dan 10,3\% jumlah kematian per tahun dari seluruh kasus kanker leher rahim di seluruh dunia (GLOBOCAN, 2013). Sementara itu, di Indonesia, menurut data Riset Kesehatan Dasar 2013, prevalensi kejadian kanker di Propinsi Daerah Istimewa Yogyakarta adalah 4,1\% per 1000 penduduk dan angka kejadian kanker leher Rahim berada pada 1,5\% per 1000 penduduk. Kejadian kematian karena kasus kanker leher Rahim dapat berkembang hingga dua kali lipat dibandingkan negara maju jika program skrining kurang serta rendahnya kemampuan dan akses terhadap fasilitas pengobatan. Penanggulangan yang 


\section{(A) ABDIMAS}

https://journal.uwgm.ac.id/index.php/abdimasmahakam

E-ISSN: 2549-5755

Januari 2020, Vol. 4 No. 01

terpadu juga harus dilakukan mulai dari Puskesmas dan keberhasilan program skrining juga harus diikuti dengan pengobatan yang adekuat (Pusdatin, 2015).

Di Indonesia, program skrining kanker leher Rahim telah dicanangkan pada 21 April 2008 dan diatur dalam Permenkes No 34 tahun 2015. Permenkes tersebut menjelaskan bahwa wanita usia 30 - 50 tahun merupakan prioritas dalam kegiatan skrining melalui pemeriksaan papsmear dan inspeksi visual asam asetat (IVA). Bahkan, pemerintah telah membentuk tim terlatih yang terdiri dari ribuan tenaga kesehatan meliputi dokter dan bidan untuk melakukan kegiatan skrining kanker leher rahim tersebut (Kemenkes, 2015).

Dukungan pemerintah dalam kegiatan skrining kanker leher rahim sangatlah besar. Bentuk dukungan lain selain adanya Permenkes No.34 tahun 2015 juga ditunjukkan dengan disebutkannya pemeriksaan skrining kanker leher rahim sebagai salah satu bentuk layanan skrining preventif sekunder selektif dalam pedoman skrining kesehatan yang diterbitkan oleh Badan Penyelenggara Jaminan Sosial (BPJS). Skrining kanker lain yang disebutkan dalam pedoman tersebut adalah skrining kanker payudara. Kegiatan skrining lain yang disebutkan adalah skrining preventif primer, yaitu kegiatan skrining untuk penyakit yang berdampak biaya besar seperti hipertensi dan diabetes mellitus tipe II (BPJS, 2014)

Wanita usia subur yang melalukan skrining dapat memperoleh manfaat dengan adanya perilaku deteksi dini adanya perubahan pada kondisi leher rahim atau serviksnya. Masa yang dibutuhkan untuk seseorang mengalami kejadian kanker memiliki rentang yang cukup panjang mulai dari 3 hingga 20 tahun sejak dimulainya infeksi Human Papilloma Virus(HPV) sampai terjadi kanker (Ellenson \& Pirog, 2010).

Pengetahuan seseorang terhadap suatu perilaku sehat memiliki hubungan yang signifikan dengan bagaimana orang tersebut melakukan suatu perilaku sehat. Minat wanita usia subur untuk melakukan pemeriksaan IVA berhubungan secara signifikan dengan pengetahuannya tentang kanker serviks dan IVA ( $\mathrm{p}=0,039)$. Dengan adanya pengetahuan yang baik, kesadaran pun muncul sehingga wanita usia subur memiliki minat untuk melakukan pemeriksaan skrining kanker leher rahim (Maijayanti, Mawarti, \& Ernawati, 2019). Peluang peningkatan minat melalui peningkatan pengetahuan tentang kesehatan reproduksi inilah yang dimanfaatkan untuk meningkatkan kesadaran terhadap kesehatan.

Jumlah wanita usia subur di Pedukuhan Druwo Kecamatan Sewon Bantul lebih dari 200 populasi. Namun, wanita usia subur yang melakukan pemeriksaan IVA baru 5 orang $(<2,5 \%)$. Hal ini tidak berbanding lurus dengan gencarnya program promosi kesehatan yang dilakukan oleh Puskesmas Sewon II yang merupakan Puskesmas membawahi wilayah tersebut. Kegiatan mengenai deteksi dini kanker leher rahim selama ini telah dilakukan oleh bidan atau tenaga kesehatan lain melalui Posyandu balita yang ada.

\section{Metode}

Kegiatan pengabdian masyarakat ini dilakukan melalui 3 tahap, yaitu tahap assessment dan persiapan, tahap pelaksanaan dan tahap evaluasi tindak lanjut. Tahap persiapan diawali dengan melakukan koordinasi dengan ketua kelompok PKK untuk menentukan materi serta ibu-ibu yang potensial untuk dilatih menjadi penyambung informasi dari Puskesmas atau pakar yang di tunjuk kepada anggota kelompok PKK. Setelah materi ditentukan, tim pelaksana dibantu mahasiswa menyusun media penyuluhan seperti lembar balik, leaflet, dan video. 
https://journal.uwgm.ac.id/index.php/abdimasmahakam

E-ISSN: 2549-5755

Januari 2020, Vol. 4 No. 01

Tahap pelaksanaan dilakukan dengan memulai proses pemberian kuesioner untuk mengukur pengetahuan ibu-ibu anggota PKK tentang beberapa permasalahan kesehatan reproduksi perempuan. Selanjutnya, proses penyuluhan diberikan mengenai kanker leher rahim dan upaya skrining yang dapat dilakukan. Setelah proses penyuluhan, dilakukan proses pemilihan kader yang akan menjadi penyambung informasi dari tenaga kesehatan yang ada di Puskesmas dengan anggota PKK.

Kegiatan evaluasi dan tindak lanjut kegiatan pengabdian masyarakat ini dilakukan berupa kegiatan pendampingan, konsultasi, dan pemeriksaan IVA serta SADARI (pemeriksaan payudara sendiri). Promosi kegiatan pemeriksaan tersebut dilakukan oleh kader yang telah dibentuk.

\section{Hasil dan Pembahasan}

Tahap Assessment dan Persiapan

Pada tahap assessment dan persiapan, diperoleh informasi bahwa ibu-ibu anggota PKK merasakan kurangnya pengetahuan dan kesempatan untuk mendapatkan informasi secara langsung dari petugas kesehatan. Informasi terkadang diperoleh melalui smartphone/android atau dari obrolan dengan tetangga. Sumber informasi tersebut dirasa kurang meyakinkan karena mereka tidak mengetahui apakah informasi atau jawaban yang diperoleh benar atau tidak. Beberapa informasi mengenai kesehatan yang diinginkan adalah tentang kanker leher rahim, kanker payudara, kontrasepsi, ASI (air susu ibu), serta penatalaksanaan anak sakit.

Berdasarkan hasil assessment yang dilakukan, maka tim menyusun media yang dapat digunakan berupa lembar balik, leaflet, dan video.

\section{Tahap Pelaksanaan}

Kegiatan pemberian informasi mengenai kanker leher rahim merupakan informasi awal yang diberikan pada kegiatan pertemuan bulanan PKK. Kegiatan penyuluhan diberikan oleh ketua tim pelaksana. Sebelum dilakukan penyuluhan, hasil pengukuran pengetahuan ibu-ibu PKK tentang kesehatan reproduksi khususnya tentang kanker leher rahim masih rendah. Nilai ratarata pengetahuan ibu-ibu PKK tentang kanker leher rahim adalah 11.

\begin{tabular}{lll}
\multicolumn{3}{l}{ Tabel 1. Analisis pengukuran pengetahuan tentang kanker leher rahim } \\
\hline Nilai rata-rata & Nilai minimal & Nilai maksimal \\
\hline 11 & 8 & 14 \\
\hline
\end{tabular}

Berdasarkan hasil pengukuran pengetahuan ibu-ibu anggota PKK tentang kanker leher rahim, diketahui bahwa sebagian besar dari mereka tidak mengetahui perlunya pemeriksaan skrining IVA, waktu yang tepat untuk pemeriksaan, serta alur yang dapat dilakukan saat ingin melakukan pemeriksaan skrining.

Setelah kegiatan penyuluhan, tim pelaksana membentuk kader yang ditunjuk oleh tim pelaksana dan pengurus PKK. Kader yang dibentuk diberikan informasi tambahan dan media untuk memberikan informasi pada kegiatan PKK selanjutnya. Kegiatan pembentukan kader ini dilakukan sebagai upaya untuk memfasilitasi pemberian informasi mengenai kesehatan. Optimalisasi kader yang juga merupakan bagian dari ibu-ibu PKK dilakukan untuk mengatasi permasalahan kurangnya akses informasi mengenai kesehatan sementara kegiatan penyuluhan kesehatan lebih sering diberikan melalui kegiatan Posyandu Balita. 
E-ISSN: 2549-5755

Januari 2020, Vol. 4 No. 01

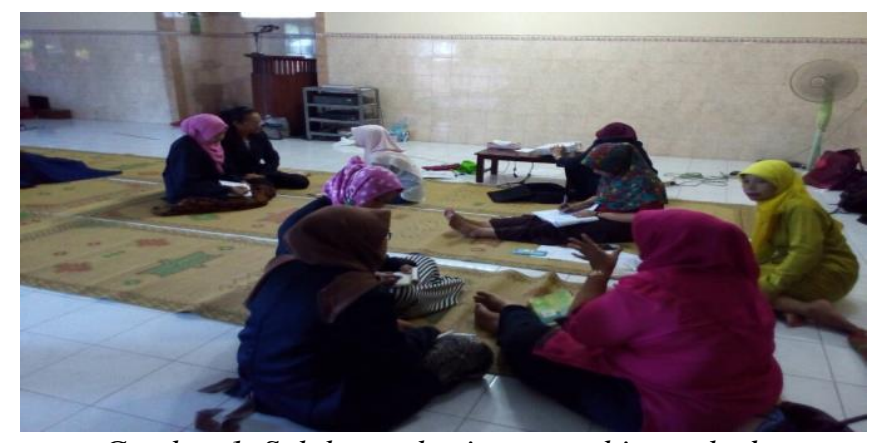

Gambar 1. Salah satu kegiatan pembinaan kader

\section{Tahap Evaluasi dan Tindak Lanjut}

Tahap evaluasi dilakukan dengan melakukan pengukuran ulang pengetahuan ibu-ibu PKK mengenai kesehatan reproduksi khususnya tentang kanker leher rahim. Berdasarkan pengukuran yang diperoleh, ditunjuk 5 orang ibu-ibu yang dipilih menjadi kader. Kader tersebut selanjutnya melakukan promosi kegiatan pemeriksaan deteksi dini kanker leher rahim melalui kegiatan pemeriksaan IVA dan kanker payudara dengan SADARI. Kegiatan pemeriksaan IVA dan SADARI dilakukan oleh tim pelaksana dibantu oleh 6 mahasiswi Prodi Kebidanan Program Sarjana Terapan UNISA Yogyakarta.

Kegiatan pemeriksaan diikuti oleh 27 ibu-ibu. Berdasarkan pemeriksaan tersebut, 2 orang dianjurkan untuk melakukan pemeriksaan lanjut di Puskesmas.

\section{Simpulan dan rekomendasi}

Kegiatan pengabdian masyarakat pembentukan kelompok PKK sebagai pusat informasi berjalan dengan lancar. Tahap awal yang dilakukan dengan pengukuran pengetahuan dan penggalian kebutuhan informasi ibu-ibu anggota kelompok PKK merupakan langkah awal untuk menentukan tahapan kegiatan selanjutnya. Luaran dari kegiatan pengabdian masyarakat ini adalah terbentuknya kelompok PKK sebagai pusat informasi kesehatan perempuan. Rekomendasi yang dihasilkan adalah adanya pembinaan lanjut serta evaluasi program bekerjasama dengan Puskesmas Sewon II yang melingkupi wilayah Pedukuhan Druwo, Bangunharjo, Sewon, Bantul. 
https://journal.uwgm.ac.id/index.php/abdimasmahakam

E-ISSN: 2549-5755

Januari 2020, Vol. 4 No. 01

\section{Daftar Pustaka}

BPJS, K. (2014, January 1). BPJS Kesehatan. Retrieved from BPJS Kesehatan Web site: http://bpjs-kesehatan.go.id

Ellenson, L. H., \& Pirog, E. C. (2010). The Female Genital Tract Chapter 22. In Robbins and Cotran Pathologic Basis of Disease. 8th Edition (pp. 1017-1024). Philadelphia: Sanders Elsevier.

GLOBOCAN. (2013, December 12). International Agency for Research on Cancer. Retrieved from International Agency for Research on Cancer Web site: http://www.iarc.fr

Kemenkes. (2015). Kementerian Kesehatan Republik Indonesia. Retrieved from Kemenkes Web site: www.depkes.go.id

Maijayanti, D., Mawarti, R., \& Ernawati, D. (2019). Hubungan Pengetahuan Kanker Serviks dengan Minat Melakukan IVA pada Wanita Usia Subur di Dusun Jetis Kretek Bantul. Retrieved from Perpustakaan Unisa Yogyakarta Web site: www.lib.unisayogya.ac.id

Pusdatin. (2015). Profil Kesehatan Indonesia Tahun 2015. Jakarta: Kemenkes RI. 